\title{
The Relationship between Gender, Age, and Attitude toward Mathematics among Malaysian Gifted Students
}

\author{
Mohd Fadzil Bin Kamarudin, Mohd Hasrul Bin Kamarulzaman, Noriah Mohd Ishak \\ Pusat PERMATApintar ${ }^{\mathrm{TM}}$ Negara, Universiti Kebangsaan Malaysia, 43600 UKM Bangi, Malaysia
}

How to cite this paper: Kamarudin, M. F. B., Kamarulzaman, M. H. B., \& Ishak, N. M. (2018). The Relationship between Gender, Age, and Attitude toward Mathematics among Malaysian Gifted Students. The Educational Review, USA, 2(8), 410-416. http://dx.doi.org/10.26855/er.2018.08.001

Corresponding author: Mohd Fadzil Bin Kamarudin, Pusat PERMATApintarTM Negara, Universiti Kebangsaan Malaysia, 43600 UKM Bangi, Malaysia.

\begin{abstract}
Students' attitude is one of the elements that call for discussion in providing gifted education for gifted students. Specifically, students' attitude towards particular subjects contribute to their achievements in those subjects. This paper highlights students' attitude within the scope of mathematics. In Malaysia education system, mathematics is one of the core subjects and needs to be mastered by students to achieve excellence in learning. Thus, the mastery of mathematics among gifted students should be studied and discussed especially of their attitude towards mathematics. This paper presents the results of a study that examines the relationship between age, gender and attitude of gifted students towards mathematics based on their interest towards mathematics. A total of 128 gifted students aged 11 until 16 years old participated in the study. All of the students were selected from various Malaysian public schools via a special selection process before becoming full time students at Malaysia National Gifted Centre. The findings reveal that there was no relationship between age, gender and attitude of the gifted students toward mathematics.
\end{abstract}

Keywords

Attitude, Gifted Students, Relationship, Age, Gender

\section{Introduction}

Gifted students are known for their preciosity and possess different characteristics compared to other students as well as among themselves (Bekirogullari \& Gur, 2011). There are certain identified behaviors that can influence their achievement in Mathematics(Leu \& Chiu, 2015). The variety of their characteristics intrigue researchers and educators alike towards establishing an education that is appropriate with their ability. Following this pursuit, Malaysia has embarked on an effort towards developing the potentials of gifted students by providing a fully residential school in preparing a special education toward gifted and talented student since 2011(Isman, Yassin, Ishak, Yunus, \& Majid, 2012). All of gifted and talented students were selected throughout Malaysia, regardless of age and gender via a special selection process such as UKM1 test, UKM2 test and PERMATApintar School holiday camp. Students selected will attend college for five years and need to do some research in science and mathematics. Since all the gifted students who participated in this study have various characteristics, this research has to be conducted to ensure that every student gets an education that suits their needs.

Most studies conducted related to the attitude of gifted students have focused on creativity (Kim, Roh, \& Cho, 2016; H. Uzunboylu, Cavus, Tekin, \& Taşğin, 2009), emotion (Minas, Machů, \& Morysová, 2016), leaderships (Laborda et al., 2014), 
and personality (BeŞOluk \& Çakır, 2014; Minas, Machů, Kočvarová, \& Kopřivová, 2016). Nonetheless, there is a very small number of studies that look into the age of students and its relationship with their attitude toward mathematics such as teaching approach (Savelsbergh et al., 2016), teacher knowledge (Oppermann, Anders, \& Hachfeld, 2016), motivational variables (García, Rodríguez, Betts, Areces, \& González-Castro, 2016). Gender difference in gifted identification is one of the topics that has always been discussed in gifted education field such as the number of gifted students selected in joining the gifted program(Petersen, 2013), mathematics achievement(Felson \& Trudeau, 1991; Fraser, 1994; Preckel, Goetz, Pekrun, \& Kleine, 2008). Petersen (2013) found that boys were 1.19 times more likely to be identified as gifted and selected to join the gifted program compared to girls. One of the reasons why lesser girls are joining the program is peer pressure (Read, 1991). However, it was found that gender difference is not a factor that influences the attitude toward mathematics (Felson \& Trudeau, 1991; Friedman-Sokuler \& Justman, 2016; Hüseyin Uzunboylu, Ozdamli, Keshavarzi, \& Ahmadi, 2013). Fraser (1994) and Ganley and Lubienski (2016) found that students in public schools have no significant difference in their attitude toward mathematics. Previous researches have shown mixed results in terms of gifted students' interest in mathematics. It is important to examine if similar results could be yielded from the Malaysian gifted students. Therefore the objective of this study is to investigate the relationships between gender, age and percentage of their impact toward gifted student's attitude in mathematics in Malaysia.

\section{Methodology}

Table 1. Division of statements into factors.

\begin{tabular}{ll}
\hline Factors & \multicolumn{1}{c}{ Statements } \\
\hline Interested in mathematics & Mathematics is very interesting to me \\
Mathematics is very fascinating and fun. \\
I enjoy seeing how rapidly and accurately when I work out \\
math problems \\
Mathematics is something which I enjoy great deal. \\
I really like Mathematics \\
Mathematics is a subject in school which I have enjoyed \\
studying. \\
I am happier in Mathematics class than in any other subject \\
I feel at ease in a Mathematics class. \\
Mathematics is as important as any other subject. \\
I feel a definite positive reaction to Mathematics. \\
I am always nervous in Mathematics class \\
It scare me to have to take Mathematics \\
My mind goes blank and I am unable to think when solving \\
Mathematics \\
I feel a sense of insecurity when attempting Mathematics \\
I am afraid of doing word problems. \\
Mathematics makes me feel uncomfortable, restless, irrita- \\
ble and impatient \\
When I hear the word Mathematics, I have feeling of dislike \\
I approach math with a feeling of hesitation, resulting from \\
a fear of not being able to do math \\
It makes me feel nervous to even think about having to do \\
Mathematics problem. \\
Mathematics is my most dreaded subject \\
\hline
\end{tabular}

This study employed a quantitative approach utilizing an adapted questionnaire comprising interest items. The survey questionnaire was designed with the primary objective to assess the attitude of the gifted students based on the interest items. The interest items were adopted from a questionnaire called Motivational Orientation towards Differentiated English Language Teaching (MoDiELT). The questionnaire comprises 20 items that ask their perceptions towards learning mathematics subject 
(Table 1). Items were rated on a 5-points scale (5=Strongly Disagree, $4=$ Disagree, $3=$ Neutral, $2=$ Agree and $1=$ Strongly Agree). The participants in this survey consisted of 128 Gifted Students aged 11 to 16 year-old of which 65 of them are boys and the rest are girls. Data were collected in Jun 2015 after mid-term examination result. It was analyzed by using SPSS software. Cronbach Alpha was chosen to calculate the validity of the data and Pearson correlation, regression and t-test methods were used to determine the relationships between age, gender and attitude towards mathematics.

\section{Results and Discussion}

\subsection{Analysis of the Validity of the Result}

Table 2. Internal Consistency Cronbach's Alpha Coefficient for the survey elements.

\begin{tabular}{lcc}
\hline Item's categories & Number of questions & Cronbach's Alpha \\
\hline Interested with Mathematics & 10 & 0.914 \\
Do not interested with Mathematics & 10 & 0.917 \\
\hline
\end{tabular}

Table 3. The value of Cronbach Alpha if item deleted (case: interested with mathematics).

\begin{tabular}{lc}
\hline & $\begin{array}{l}\text { Cronbach's Alpha if } \\
\text { Item Deleted }\end{array}$ \\
\hline Mathematics is very interesting to me & .898 \\
Mathematics is very fascinating and fun. & .897 \\
I enjoy seeing how rapidly and accurately when I work out math problems & .908 \\
& .904 \\
Mathematics is something which I enjoy great deal. & .898 \\
I really like Mathematics & .899 \\
Mathematics is a subject in school which I have enjoyed studying. & .917 \\
I am happier in Mathematics class than in any other subject & .917 \\
I feel at ease in a Mathematics class. & .911 \\
Mathematics is as important as any other subject. & .905 \\
I feel a definite positive reaction to Mathematics. & \\
\hline
\end{tabular}

Table 4. The value of Cronbach Alpha if item deleted (case: do not interested with mathematics).

\begin{tabular}{ll}
\hline & $\begin{array}{l}\text { Cronbach's Alpha if } \\
\text { Item Deleted }\end{array}$ \\
\hline I am always nervous in Mathematics class & .911 \\
It scare me to have to take Mathematics & .906 \\
My mind goes blank and I am unable to think when solving Mathematics & .907 \\
I feel a sense of insecurity when attempting Mathematics & .907 \\
I am afraid of doing word problems. & .916 \\
Mathematics makes me feel uncomfortable, restless, irritable and impatient & .903 \\
When I hear the word Mathematics, I have feeling of dislike & .909 \\
I approach math with a feeling of hesitation, resulting from a fear of not being able to & .909 \\
do math & .904 \\
It makes me feel nervous to even think about having to do Mathematics problem. & .912 \\
Mathematics is my most dreaded subject
\end{tabular}

The consistency of the survey was determined using Cronbach's alpha statistical factor. It is an indicator of how well the condition or characteristics of the data either it can be accepted or not. Generally, reliability coefficients of Cronbach's alpha of 0.70 or more are considered acceptable and indicate that the survey element is consistent and valid. Tables $2-4$ 
show that the coefficient of the Cronbach's Alpha of two categories items for the survey elements is close to 1 . Therefore data obtained are very reliable in yielding the result for the purpose of the study.

\subsection{Attitude of Gifted and Talented Student toward Mathematics Subject}

\subsubsection{Age Approach}

The relationship between the age of gifted students and their attitude toward mathematics was investigated by using Pearson correlation method. Scatterplot was used to determine the pattern of data collected and to evaluate the quality of the relationship. Figure 1 and Figure 2 show that there is no significant relationship between age and attitude of gifted students in which only $12 \%$ affected the positive attitude and $4 \%$ affected negative attitude of gifted students toward mathematics.

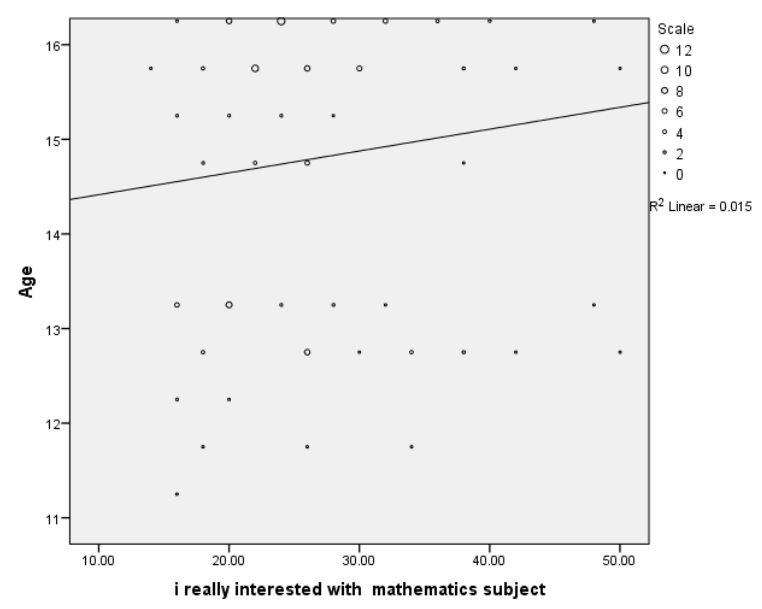

Figure 1. Relationship between the age of gifted and talented students and their attitude toward mathematics subject (case: interested with mathematics).

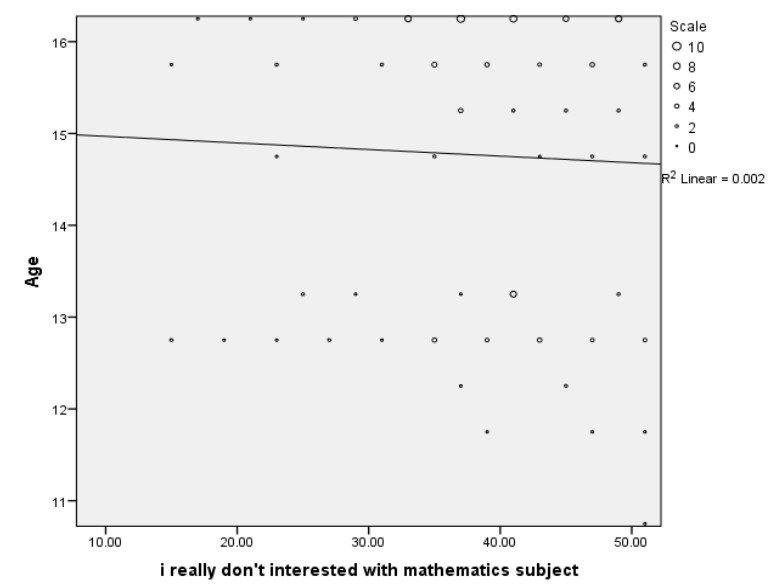

Figure 2. Relationship between the age of gifted and talented students and their attitude toward mathematics subject (case: do not interest with mathematics). 
Table 5. Pearson correlation between the age of gifted and talented students and their attitude toward mathematics subject (case: interested with mathematics).

\begin{tabular}{llll}
\hline & & Age & $\begin{array}{l}\text { I really interested with } \\
\text { mathematics subject }\end{array}$ \\
\hline Age & Pearson Correlation & 1 & .121 \\
& Sig. (2-tailed) & & .174 \\
& $\mathrm{~N}$ & 128 & 128 \\
& & .121 & 1 \\
I really interested with & Pearson Correlation & .174 & \\
mathematics subject & Sig. (2-tailed) & 128 & 128 \\
& $\mathrm{~N}$ & &
\end{tabular}

Table 6. Pearson correlation between the age of gifted and talented students and their attitude toward mathematics subject (case: do not interest with mathematics).

\begin{tabular}{|c|c|c|c|}
\hline & & Age & $\begin{array}{l}\text { I really don't interest } \\
\text { with mathematics } \\
\text { subject }\end{array}$ \\
\hline Age & $\begin{array}{l}\text { Pearson Correlation } \\
\text { Sig. (2-tailed) }\end{array}$ & 1 & $\begin{array}{l}-.042 \\
.639\end{array}$ \\
\hline $\begin{array}{l}\text { I don't interest with } \\
\text { mathematics subject }\end{array}$ & $\begin{array}{l}\mathrm{N} \\
\text { Pearson Correlation } \\
\text { Sig. (2-tailed) }\end{array}$ & $\begin{array}{l}128 \\
-.042 \\
.639\end{array}$ & $\begin{array}{l}128 \\
1\end{array}$ \\
\hline & $\mathrm{N}$ & 128 & 128 \\
\hline
\end{tabular}

\subsubsection{Gender Approach}

Table 7 describes the mean and standard deviations of each group consist of male and female students. The means represent the average number of students who are really interested or not interested in mathematics subject on a five-point scale. It is obvious that the average number of male students who were really interested in mathematics subject is 24.5846 whereas for female student is 25.8095 .

Table 7. The average number of students who are interest and do not intested in mathematics.

\begin{tabular}{|c|c|c|c|c|c|}
\hline & Gender & $\mathrm{N}$ & Mean & Std. Deviation & Std. Error Mean \\
\hline \multirow{2}{*}{$\begin{array}{l}\text { I really interested } \\
\text { with mathematics subject }\end{array}$} & male & 65 & 24.5846 & 8.13152 & 1.00859 \\
\hline & female & 63 & 25.8095 & 7.32617 & .92301 \\
\hline \multirow{2}{*}{$\begin{array}{l}\text { I don't interest } \\
\text { with mathematics subject }\end{array}$} & male & 65 & 38.8154 & 8.62390 & 1.06966 \\
\hline & female & 63 & 37.8571 & 8.65999 & 1.09106 \\
\hline
\end{tabular}

Table 8 describes independent sample t-test information to ascertain whether there is a significant difference between male and female students in relation to a number of students either interested or not interested in mathematics. The test revealed that there is no significant difference between male and female students in relation to the number of students who are interested in mathematics $(t=-0894, d f=126, p>0.05)$. Besides that, the same goes to the number of students who are not interested in mathematics subject. There is no evidence against the idea that there is significant difference between male and female students in relation to the number of students who are not interested in mathematics $(t=0.627, \mathrm{df}=126, \mathrm{p}>0.05)$. 
Table 8. The relation of gender and gifted student's attitude toward mathematics.

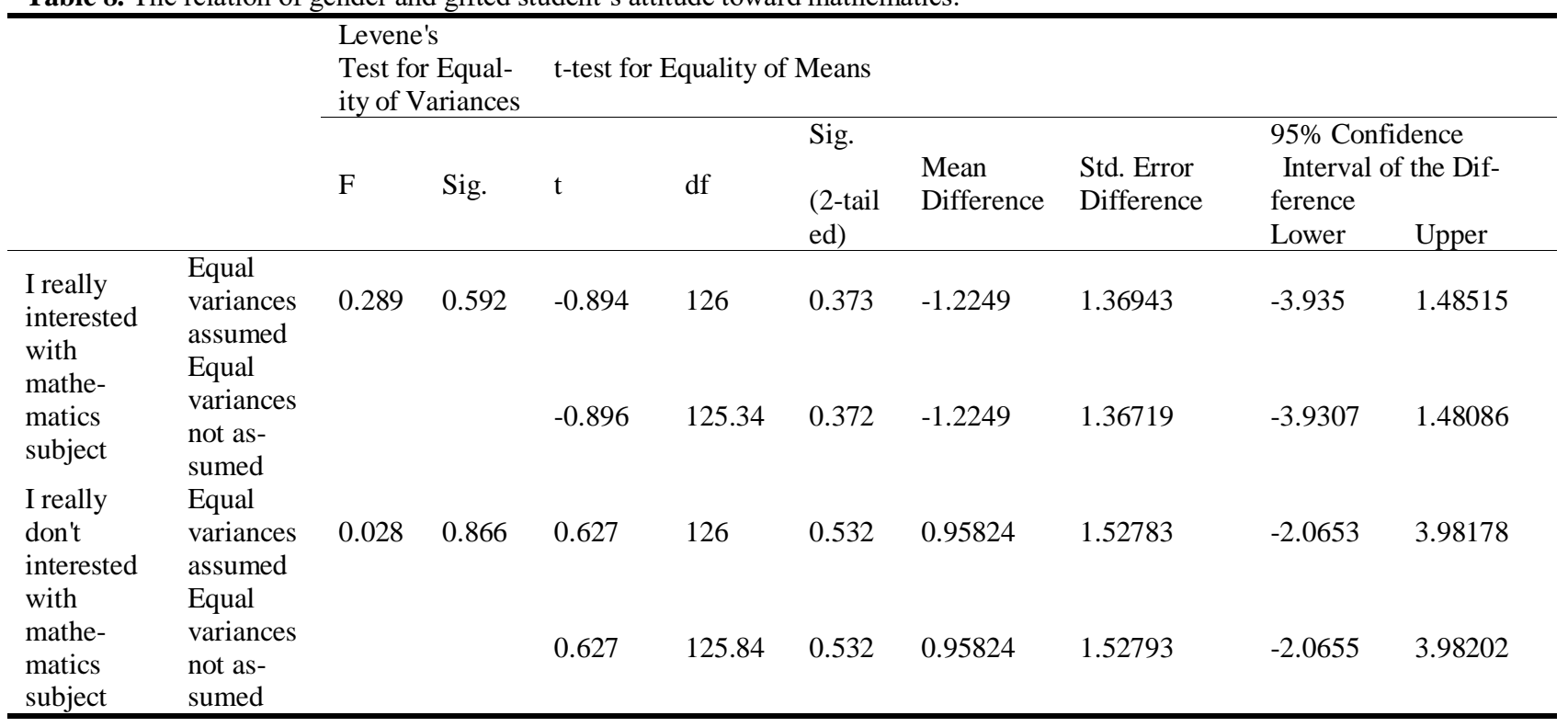

\section{Conclusion}

The difference between age and gender are common elements in the assessment because it determines the suitability the subject interacts with situations and circumference. Different situation or context will generate different outcomes to the factors of age and gender of the participants, which sometimes favor females rather than males, or vice versa. In the case of the attitude of gifted students toward mathematics, there is no significant difference between male and female gifted students. Beside that the student's interest toward mathematics also is not affected by increasing ages.

\section{References}

Bekirogullari, Z., \& Gur, C. (2011). International Conference on Education and Educational Psychology 2010 Do Gifted Children Have Similar Characteristics?: Observation of Three Gifted Children. Procedia - Social and Behavioral Sciences, 12, 493-500. doi: http://dx.doi.org/10.1016/j.sbspro.2011.02.061

BeŞOluk, Ş., \& Çakır, L. (2014). ERPA International Congress on Education, ERPA Congress 2014, 6-8 June 2014, Istanbul, TurkeyThe Relationship between Underachievement of Gifted Students and their Attitudes toward School Environment. Procedia - Social and Behavioral Sciences, 152, 1034-1038. doi: http://dx.doi.org/10.1016/j.sbspro.2014.09.269

Felson, R. B., \& Trudeau, L. (1991). Gender Differences in Mathematics Performance. Social Psychology Quarterly, 54(2), 113-126. doi: $10.2307 / 2786930$

Fraser, E. J. P. (1994). Problems of Gender in University Mathematics. British Educational Research Journal, 20 (2), $147-154$.

Friedman-Sokuler, Naomi, \& Justman, Moshe. (2016). Gender Streaming and Prior Achievement in High School Science and Mathematics. Economics of Education Review, 53, 230-253. doi: http://dx.doi.org/10.1016/j.econedurev.2016.04.004

Ganley, C. M., \& Lubienski, S. T. (2016). Mathematics Confidence, Interest, and Performance: Examining Gender Patterns and Reciprocal Relations. Learning and Individual Differences, 47, 182-193. doi: http://dx.doi.org/10.1016/j.lindif.2016.01.002

García, T., Rodríguez, C., Betts, L., Areces, D., \& González-Castro, P. (2016). How Affective-Motivational Variables and Approaches to Learning Predict Mathematics Achievement in Upper Elementary Levels. Learning and Individual Differences, 49, 25-31. doi: http://dx.doi.org/10.1016/j.lindif.2016.05.021

Isman, A. Y., Siti, F. M., Ishak, N. M., Yunus, M. M., \& Majid, R. A. (2012). 3rd. International Conference on New Horizons in Education INTE 2012 the Identification of Gifted and Talented Students. Procedia - Social and Behavioral Sciences, 55, 585-593. doi: http://dx.doi.org/10.1016/j.sbspro.2012.09.540

Kim, M. K., Roh, Il S., \& Cho, M. K. (2016). Creativity of Gifted Students in an Integrated Math-Science Instruction. Thinking Skills and Creativity, 19, 38-48. doi: http://dx.doi.org/10.1016/j.tsc.2015.07.004 
Laborda, J. G., Ozdamli, F. M., Yasar, B. A., Yazid, A., Ishak, N. M., \& Abidin, M. H. Z. (2014). The 5th World Conference on Educational SciencesThe Relationship between Domains of Empathy and Leadership Skills among Gifted and Talented Students. Procedia - Social and Behavioral Sciences, 116, 765-768. doi: http://dx.doi.org/10.1016/j.sbspro.2014.01.294

Leu, Y. C., \& Chiu, M. S. (2015). Creative Behaviours in Mathematics: Relationships with Abilities, Demographics, Affects and Gifted Behaviours. Thinking Skills and Creativity, 16, 40-50. doi: http://dx.doi.org/10.1016/j.tsc.2015.01.001

Minas, M., Machů, E., Kočvarová, I., \& Kopřivová, R. (2016). Future Academy Multidisciplinary Conference "ICEEPSY \& CPSYC \& icPSIRS \& BE-ci" 13-17 October 2015 Istanbul Tendencies of Gifted Pupils toward Selected Aspects of Conformist Behavior in the Context of Their Relationships with Classmates. Procedia - Social and Behavioral Sciences, 217, 214-221. doi: http://dx.doi.org/10.1016/j.sbspro.2016.02.068

Minas, M., Machů, E., \& Morysová, D. (2016). Future Academy Multidisciplinary Conference "ICEEPSY \& CPSYC \& icPSIRS \& BE-ci" 13-17 October 2015 Istanbul Analysis of The Emotion of Fear in Gifted Children and Its Use in Teaching Practice. Procedia - Social and Behavioral Sciences, 217, 222-228. doi: http://dx.doi.org/10.1016/j.sbspro.2016.02.071

Oppermann, E., Anders, Y., \& Hachfeld, A. (2016). The Influence of Preschool Teachers' Content Knowledge and Mathematical Ability Beliefs on Their Sensitivity to Mathematics in Children's Play. Teaching and Teacher Education, 58, 174-184. doi: http://dx.doi.org/10.1016/j.tate.2016.05.004

Petersen, J. (2013). Gender Differences in Identification of Gifted Youth and in Gifted Program Participation: A Meta-Analysis. Contemporary Educational Psychology, 38(4), 342-348. doi: http://dx.doi.org/10.1016/j.cedpsych.2013.07.002

Preckel, F., Goetz, T., Pekrun, R., \& Kleine, M. (2008). Gender Differences in Gifted and Average-Ability Students: Comparing Girls' and Boys' Achievement, Self-Concept, Interest, and Motivation in Mathematics. Gifted Child Quarterly, 52(2), 146-159. doi: $10.1177 / 0016986208315834$

Read, C. R. (1991). Gender Distribution in Programs for the Gifted. Roeper Review, 13(4), 188-193. doi: 10.1080/02783199109553356

Savelsbergh, E. R., Prins, G. T., Rietbergen, C., Fechner, S., Vaessen, B. E., Draijer, J. M., \& Bakker, A. (2016). Effects of Innovative Science and Mathematics Teaching on Student Attitudes and Achievement: A Meta-Analytic Study. Educational Research Review, 19, 158-172. doi: http://dx.doi.org/10.1016/j.edurev.2016.07.003

Uzunboylu, H., Cavus, N., Tekin, M., \& Taşğin, Ö. (2009). World Conference on Educational Sciences: New Trends and Issues in Educational SciencesAnalysis of The Creativity Level of The Gifted Students. Procedia - Social and Behavioral Sciences, 1(1), $1088-1092$. doi: http://dx.doi.org/10.1016/j.sbspro.2009.01.196

Uzunboylu, H., Ozdamli, F., Keshavarzi, A., \& Ahmadi, S. (2013). The 2nd World Conference on Educational Technology ResearchA Comparison of Mathematics Anxiety among Students by Gender. Procedia - Social and Behavioral Sciences, 83, 542-546. doi: http://dx.doi.org/10.1016/j.sbspro.2013.06.103 